\title{
Proses Berpikir Siswa Berkecerdasan Matematis Logis Dalam Menyelesaikan Masalah Matematis "Ill Structured Problems"
}

\author{
Siti Nurjanah ${ }^{1}$, Erry Hidayanto ${ }^{1}$, Swasono Rahardjo ${ }^{1}$ \\ ${ }^{1}$ Pendidikan Matematika-Universitas Negeri Malang
}

\begin{tabular}{l} 
INFO ARTIKEL \\
\hline Riwayat Artikel: \\
Diterima: 17-05-2019 \\
Disetujui: 11-11-2019 \\
\hline
\end{tabular}

\section{Kata kunci:}

thinking process; logical mathematical intelligence; ill structured problems; proses berpikir; kecerdasan matematika logis; ill structured problems

\author{
Alamat Korespondensi: \\ Siti Nurjanah \\ Pendidikan Matematika \\ Universitas Negeri Malang \\ Jalan Semarang 5 Malang \\ E-mail: sitinurjanah418@yahoo.com
}

\section{ABSTRAK}

Abstract: Understanding the thinking process of students in mathematical problem solvingis very important for the teacher. Every student has different abilities in problems solving. Ill structured problems depend on the type of intelligence they have. This research uses descriptive qualitative research. The purpose of this study is to describe the thinking process of students with logical mathematical intelligence in solving limited mathematical information problems. The subject of this study consisted of one grade VIII junior high school student who had high logical mathematical intelligence. The results showed that the thinking process of students with logical mathematical intelligence in completing "Ill structured problems" used several stages of completion in the form of: (1) solving the problem (parsing the problem) into several important parts, (2) connecting various information also used, and (3) completing by adding information and changing information, so that it will be easier to solve problems Ill structured problems.

\begin{abstract}
Abstrak: Memahami proses berpikir siswa dalam menyelesaikan masalah matematika sangat penting bagi guru. Setiap siswa memiliki kemampuan yang berbeda-beda dalam memecahkan masalah Ill structured problems tergantung dari jenis kecerdasan yang dimilikinya. Penelitian ini menggunakan jenis penelitian kualitatif deskriptif. Tujuan penelitian ini adalah untuk mendeskripsikan proses berpikir siswa berkecerdasan matematis logis dalam menyelesaikan masalah matematis informasi terbatas. Subjek penelitian ini terdiri satu orang siswa kelas VIII SMP yang memiliki kecerdasan matematis logis yang tinggi. Hasil penelitian menunjukkan bahwa proses berpikir siswa berkecerdasan matematis logis dalam menyelesaikan "Ill structured problems" menggunakan beberapa tahap penyelesaian berupa (1) memecah masalah (mengurai masalah) menjadi beberapa bagian penting, (2) menghubungkan berbagai informasi juga digunakan, dan (3) menyelesaikan dengan cara menambah informasi dan mengubah informasi sehingga akan lebih mudah dalam menyelesaikan masalah Ill structured problems.
\end{abstract}

Siswono (2008) menjelaskan bahwa berpikir merupakan suatu kegiatan mental yang dialami seseorang bila mereka dihadapkan pada suatu masalah atau situasi yang harus dipecahkan. Berpikir menurut Kuswana (2013) adalah proses menggunakan akal budi untuk mempertimbangkan dan memutuskan sesuatu, menimbang-nimbang dalam ingatan. Menurut Mayer (1992) berpikir adalah perilaku yang menghasilkan pemecahan masalah atau yang mengarahkan pada solusi. Jadi, dapat disimpulkan bahwa berpikir adalah suatu kegiatan mental untuk memutuskan sesuatu saat dihadapkan pada suatu situasi atau masalah. Memahami proses berpikir siswa dalam menyelesaikan masalah matematika sangat penting bagi guru. Guru harus memahami cara berpikir siswa, cara siswa mengolah informasi yang diterima sekaligus bertindak sebagai pengarah untuk mengubah cara berpikir siswa sehingga guru dapat mengetahui jenis kesalahan siswa ketika menyelesaikan masalah matematika (Rofi'i, 2016).

Masalah didefinisikan oleh Dewey (1933) sebagai segala sesuatu yang membuat seseorang bingung serta membuat keyakinan menjadi tidak pasti. Masalah juga didefinisikan sebagai situasi yang dihadapi seseorang dengan beberapa hambatan ketika menyelesaikan masalah. Artinya, tugas menjadi masalah jika melibatkan titik yang tidak dapat diselesaikan oleh pemecah masalah (Kroll \& Miller, 1993). Jadi, dapat disimpulkan bahwa masalah adalah suatu kondisi yang membingungkan serta membutuhkan solusi karena ada beberapa hambatan dalam menyelesaikan masalah. Masalah matematika sangat bervariasi karena bukan hanya terkait dengan angka. Setiap masalah tentunya membutuhkan pemecahan masalah. Pemecahan masalah adalah salah satu keterampilan dasar penting yang dibutuhkan pada abad ke-21 (Rahman, 2019). Menurut Zhong, Wang, \& Chiew, (2010) 
pemecahan masalah adalah proses intelektual otak yang mengeksplorasi penjelasan serta menemukan teknik untuk masalah tertentu yang diberikan. Proses pemecahan masalah merupakan inti dari pembelajaran matematika (Saglam \& Dost, 2014).

Berdasarkan berbagai pendekatan, masalah dibagi menjadi dua yaitu masalah rutin dan masalah non-rutin. Masalah rutin terjadi ketika seorang pemecah masalah tahu cara menemukan jawaban yang benar dan tahu bahwa cara itu cocok untuk masalah tersebut (Mayer \& Hegarty, 1996). Masalah non-rutin memerlukan pengorganisasian, pengklasifikasian data yang diberikan, serta membuat hubungan dan keterampilan komputasi (Jurdak, 2006). Selain itu, masalah non rutin terjadi ketika seorang pemecah masalah tidak tahu bagaimana memecahkan masalah dan tidak dapat melihat solusi dengan jelas (Mayer \& Hegarty, 1996). Berdasarkan jenis masalah yang dipecahkan, Yee (2002) mengklasifikasikan masalah matematika menjadi dua macam, yaitu masalah tertutup (closed problems) dan masalah terbuka (open ended problems). Masalah tertutup disebut juga dengan "well structured", sedangkan masalah terbuka biasanya disebut dengan“ill structured" atau ill structured problems". Masalah illstructured adalah masalah yang kompleks dan tidak jelas (Jonassen, 1997), mempunyai beberapa jalur solusi atau tidak ada solusi sama sekali (Hung, 2015); (Kitchener \& Karen, 1983). Memecahkan masalah ill structured jauh lebih rumit dan sulit daripada memecahkan masalah well structured (Jonassen, 1997). Well structured problems adalah masalah yang informasinya lengkap, biasanya berupa masalah rutin dan dapat diselesaikan dengan teknik solusi yang telah ditetapkan. Well structured problems merupakan masalah-masalah yang terstruktur dengan baik yang memiliki keadaan awal dan tujuan yang terdefinisi dengan baik (Reed, 2015). Langkah-langkah penyelesaian ill structured problem menurut Jonassen (1997) meliputi beberapa tahap yaitu : mengartikulasikan konteks atau ruang masalah, identifikasi dan klarifikasi pendapat dan tahap membangun kemungkinan solusi, menilai viabilitas solusi alternatif, memantau ruang masalah, melaksanakan serta memantau solusi dan mengadaptasikan solusi.

Setiap siswa memiliki kemampuan yang berbeda-beda dalam memecahkan masalah matematika tergantung dari jenis kecerdasan yang dimilikinya. Gardner (1997) membagi kecerdasan manusia menjadi sembilan kecerdasan, yaitu visual spasial, lisan atau linguistik, matematis logis, kinestetik, naturalis, musik, eksistensial, interpersonal, dan intrapersonal. Pada artikel ini, peneliti hanya membahas satu jenis kecerdasan yang terkait dengan materi penelitian, yaitu kecerdasan matematis logis. Kecerdasan matematis logis merupakan kecerdasan untuk menggunakan angka, berpikir logis dalam menganalisis kasus, melihat hubungan antara informasi yang terpisah dan berbeda serta melakukan perhitungan matematis (Gardner, 1997). Kecerdasan matematis logis juga berkaitan dengan kepekaan dalam menemukan pola yang digunakan untuk melakukan kalkulasi hitung, berpikir abstrak, berpikir logis, dan berpikir ilmiah (Jamaris, 2017).

\section{METODE}

Penelitian ini menggunakan jenis penelitian kualitatif deskriptif. Tujuan penelitian ini adalah untuk mendeskripsikan proses berpikir siswa berkecerdasan matematis logis dalam menyelesaikan masalah matematis informasi terbatas. Subjek penelitian ini terdiri dari satu orang siswa kelas VIII SMP yang memiliki kecerdasan matematis logis yang tinggi. Pengumpulan data dilakukan dengan terlebih dahulu memberikan tes MIR (Multiple Intelligences Research) untuk memilih satu siswa berkecerdasan matematis logis tinggi untuk dijadikan sebagai subjek penelitian. Pemilihan subjek penelitian juga dengan memperhatikan saran dari guru di kelas tersebut. Siswa yang terpilih menjadi subjek penelitian diberikan soal tes pemecahan masalah ill structured dan dilanjutkan dengan wawancara. Wawancara dilakukan terhadap subjek penelitian untuk mengeksplorasi proses berpikirnya dalam memecahkan masalah ill structured. Pelaksanaan wawancara senantiasa berkembang sehingga tidak dapat dibuat prosedur baku tentang langkah-langkah yang dilakukan. Tugas pemecahan masalah matematis ill structured dalam penelitian ini adalah sebagai berikut.

Toko A memberikan diskon 5\% untuk pembelian pertama semua jenis barang, diskon $10 \%$ untuk pembelian kedua dan diskon $15 \%$ untuk pembelian ketiga. Sementgara itu, toko B memberlakukan buy 2 get 1 free (gratis satu setelah membeli dua barang). Jika seseorang akan membeli empat buah barang, di toko manakah ia harus berbelanja agar ia memperoleh harga paling murah?

\section{HASIL}

Berikut ini adalah hasil pekerjaan siswa A (siswa berkecerdasan matematis logis) berdasarkan langkah-langkah penyelesaian ill structured problems beserta kutipan wawancara yang dilakukan setelah subjek A mengerjakan soal ill structured problems, sebagaimana ditunjukkan pada gambar 1.

\section{Tahap Mengartikulasikan Konteks atau Ruang Masalah}

Pada tahap ini subjek mendapatkan masalah karena bimbang untuk memilih membeli barang di toko A ataukah di toko B. Hal ini tampak dari hasil wawancara berikut :

\footnotetext{
$S$ : Setelah membaca soal yang diberikan saya benar-benar bingung untuk memilih membeli barang di toko A ataukah $B$

$P$ : Bingung bagaimana?

$S$ : Ya bingung... karena sepertinya lebih murah di toko A yang diskonnya semakin besar dengan semakin banyaknya melakukan pembelian, tetapi toko B juga sepertinya murah karena beli 2 gratis 1.
} 
Selain itu, juga karena harga barangnya belum diketahui

$P$ : Setelah itu apa yang kamu lakukan?

$S$ : Saya membaca beberapa kali soalnya supaya bisa lebih memahami soal

Dari kutipan hasil wawancara di atas tampak subjek masih mengalami masalah sehingga ia memutuskan untuk membaca ulang soal yang diberikan dengan tujuan agar lebih memahami soal tersebut.

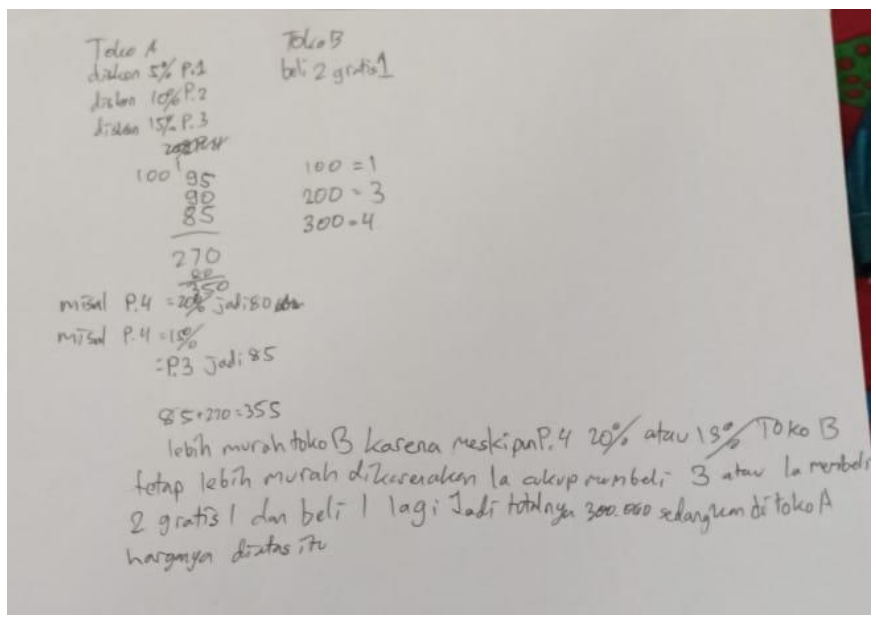

Gambar 1. Potongan Pekerjaan Subjek A

Tahap Identifikasi dan Klarifikasi Pendapat serta Tahap Membangun Kemungkinan Solusi

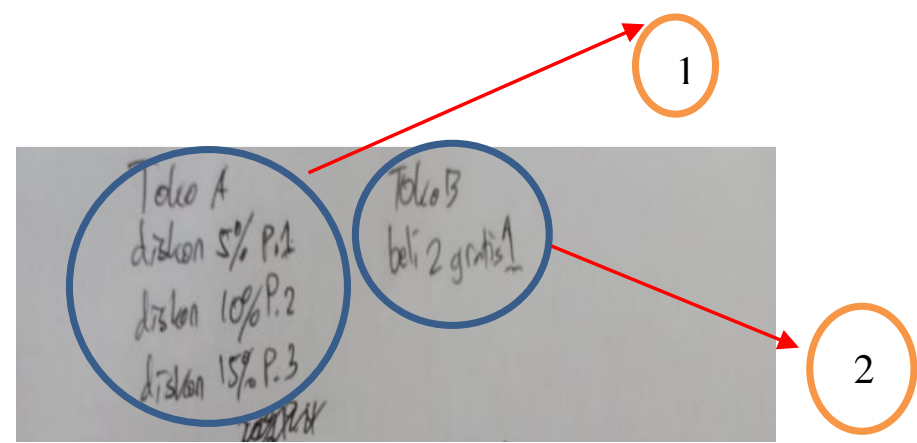

Gambar 2. Potongan Pekerjaan Subjek A

Dari potongan pekerjaan subjek A di atas terlihat bahwa subjek A mulai mengidentifikasi pemilihan pembelian yang akan dilakukan untuk memperoleh harga termurah, yaitu di toko A atau di toko B. Hal tersebut juga dapat diketahui dari hasil wawancara berikut:

$P$ : Langkah awal apa yang anda lakukan untuk menyelesaikan soal tersebut?

$S$ : Saya membuat kemungkinan solusi...

$P$ : Bagaimana caranya?

$S$ : Karena yang ditanyakan adalah di toko manakah diperoleh harga termurah, maka alternatif jawaban dari soal tersebut hanya 2 kemungkinan yaitu harga paling murah di toko A atau harga paling murah di toko $B$

$P$ : Tulisan (1) dan (2) apa maksudnya?

$S$ : Tulisan (1) maksudnya saya mencoba untuk membeli 4 barang semua di toko A, sedangkan tulisan (2) saya mencoba untuk membeli 4 barang semua di toko $B$

Subjek juga tampak melakukan proses mengurai dan menelaah masalah (berpikir analitik) menjadi beberapa bagian, hal ini tampak dari kutipan wawancara berikut ini:

$P$ : Langkah berikutnya apa?

$S$ : Saya menulis "diskon 5\% untuk pembelian pertama, diskon $10 \%$ pembelian kedua dan diskon $15 \%$ untuk pembelian Ketiga, sedangkan toko $B$ beli 2 gratis 1 
Tahap Menilai Viabilitas Solusi Alternatif

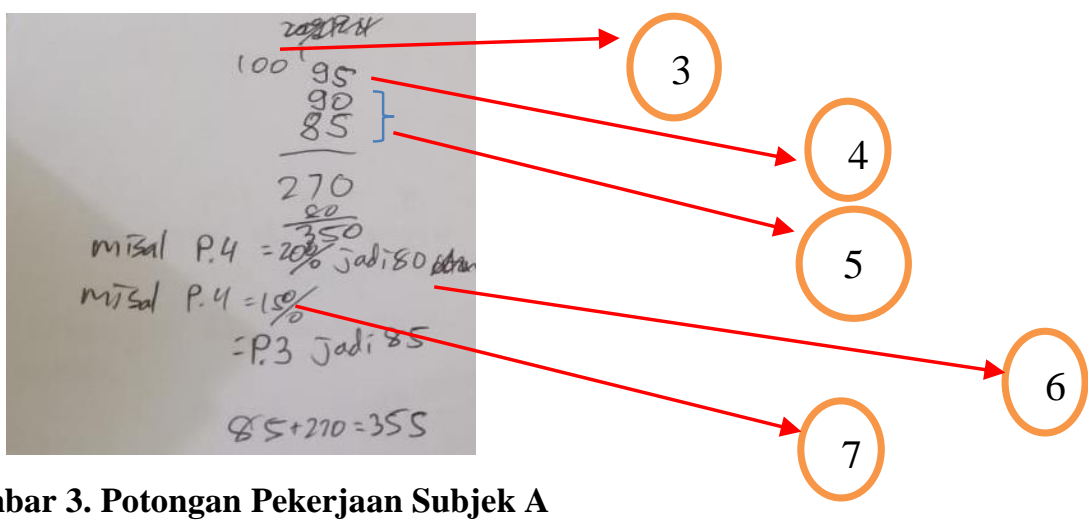

Dari potongan pekerjaan subjek A tersebut tampak jika subjek A melakukan penambahan informasi dengan memisalkan harga barang dengan 100.000 (3), hal tersebut ia lakukan untuk memudahkan proses penghitungan dan menentukan di toko mana yang paling murah harganya. (4) dan (5) adalah harga barang pada pembelian pertama, kedua dan ketiga setelah dikenakan diskon. Selanjutnya siswa A juga menambah informasi sekaligus mengubah informasi dengan memisalkan pembelian ke-4 memperoleh diskon 20\% dan 15\% (6 dan 7) padahal di soal tidak ada keterangan diskon untuk pembelian barang ke-4. Subjek A melakukan hal tersebut karena menurut pendapatnya pembelian barang yang ke-4 juga pasti mendapat diskon dan diskonnya pasti minimal 15\% ke atas (mengubah informasi). Hal tersebut dapat dilihat dari hasil kutipan wawancara berikut :

$P$ : Coba anda jelaskan langkah - langkah pengerjaan soal tersebut!

$S$ : Saya misalkan terlebih dahulu untuk harga barangnya, supaya saya bisa menentukan di toko mana yang harganya paling murah .....saya misalkan harganya 100.000 (menambah informasi)

$P$ : Kenapa kok memilih angka 100.000?

$S$ : Karena angka 100.000 lebih mudah untuk dihitung

$P$ : Kemudian apalagi yang anda lakukan?

$S$ : Menghitung harga pembelian barangnya yang di toko A....harga barang yang pertama 95.000 (diskon 5\%), harga barang kedua 90.000 (diskon 10\%) dan harga barang ketiga 85.000 (diskon 15\%) jadi total harga 3 barang sebesar 270.000. Pembelian barang yang keempat saya misalkan harga barangnya diskon 15\% atau 20\% (menambah dan mengubah informasi)

$P$ : Bagaimana kok bisa menyimpulkan bahwa harga barang keempat mendapat diskon $15 \%$ atau $20 \%$ ?

$S$ : Ya karena toko A dilihat dari diskon - diskon sebelumnya kan bisa terlihat bahwa setiap pembelian selalu mendapat diskon dan diskonnya selalu bertambah dari pembelian sebelumnya. Tapi saya juga memisalkan diskonnya 15\%

(tidak bertambah diskonnya) untuk mengecek bagaimana harga total di toko A setelah mendapat diskon 15\% atau 20\%

di pembelian keempat

Pada gambar 4 terlihat bahwa subjek A pada tahap ini melakukan penghitungan pembelian empat barang di toko B, subjek A juga melakukan penambahan informasi dengan memisalkan harga barang 100.000,00. Nomor 8 adalah pembelian satu barang seharga 100.000, nomor 9 maksudnya adalah pembelian tiga barang harganya $200.00(2 \times 100.000)$ karena toko B memberlakukan buy 2 get 1 free maka barang ketiga gratis sehingga untuk pembelian tiga barang hanya membayar 200.000 . Sedangkan no 10 maksudnya adalah membeli empat barang harganya 300.000 (3 x 100.000) satu barang tidak dihitung harganya karena gratis.

Dari gambar 5 subjek A telah melakukan penghitungan untuk mencari harga termurah, nomor 11 pada gambar diatas memperlihatkan bahwa subjek A melakukan penghitungan harga di toko B dilanjutkan penghitungan pada toko A (nomor 12). Sehingga subjek A mempunyai kesimpulan bahwa di toko B yang memberikan harga paling murah (nomor 13). Pada tahap melaksanakan serta memantau solusi subjek A memilih toko B sebagai toko yang memberikan harga paling murah. Hal tersebut juga tampak dari hasil wawancara "saya pilih toko B sebagai toko yang memberikan harga paling murah karena meskipun toko A untuk pembelian ke-4 mendapat diskon tapi tetap saja toko B yang paling murah". 
Tahap Memantau Ruang Masalah

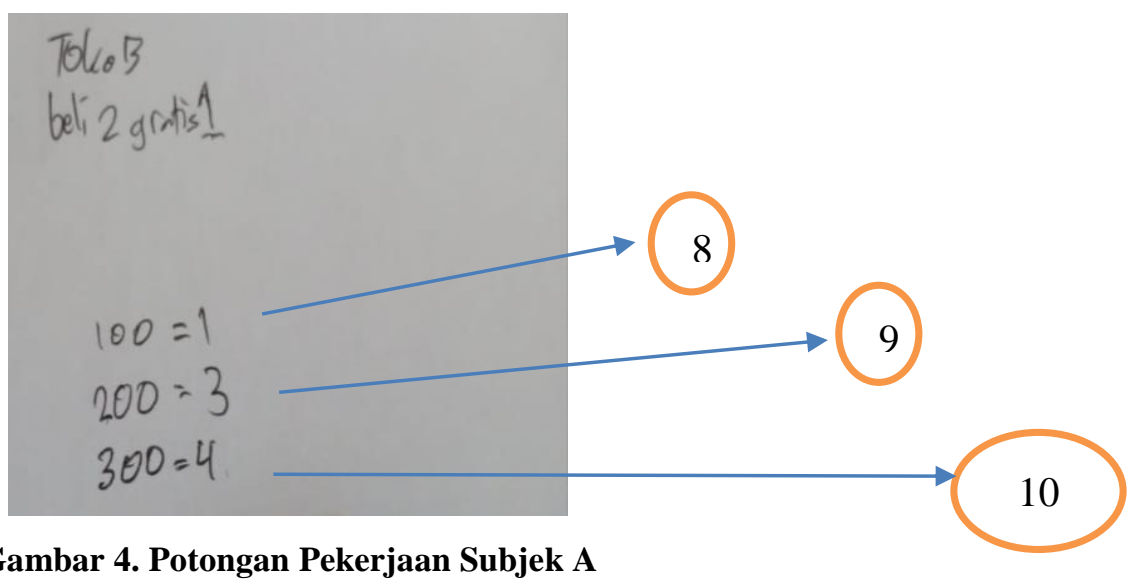

Tahap Melaksanakan dan Memantau Solusi

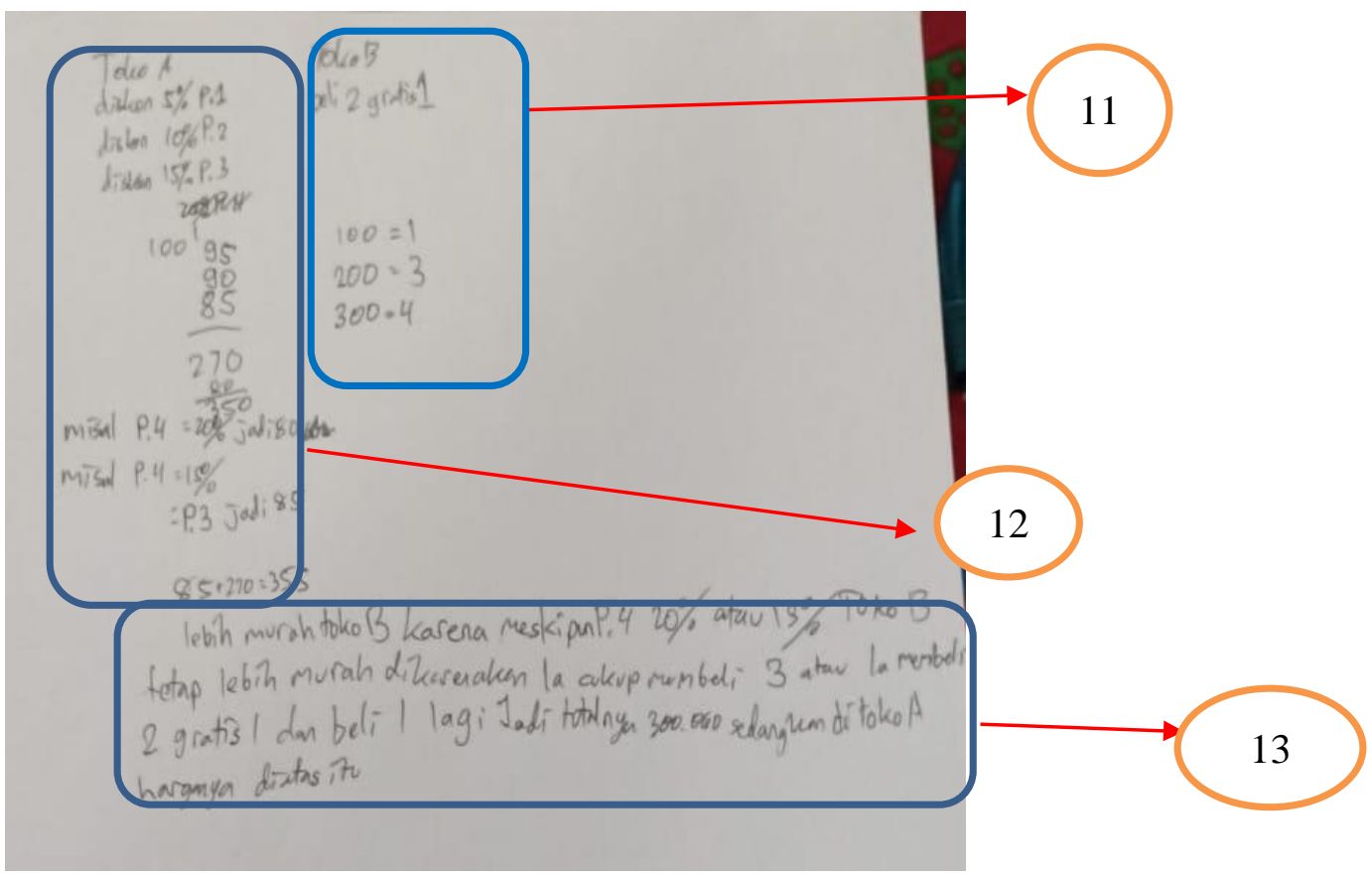

Gambar 5. Potongan Pekerjaan Subjek A

Tahap Mengadaptasikan Solusi

Pada tahap mengadaptasikan solusi, subjek A tetap memilih toko B sebagai toko yang memberikan harga termurah, hal ini sesuai dengan hasil wawancara berikut :

$P$ : Yakin masih tetap pilih toko B sebagai toko yang memberikan harga termurah?

$S:$ Iya yakin

$P$ : Kenapa kok begitu yakin, apa alasannya?

$S$ : Karena meskipun toko A memberikan diskon $15 \%$ atau $20 \%$ untuk pembelian barang ke-4 (siswa mengubah informasi, karena di soal tidak ada keterangan diskon $15 \%$ atau $20 \%$ untuk pembelian barang yang ke) tetap saja toko B yang paling murah

$P$ : Bagaimana jika diskon barang ke-4 bukan $15 \%$ atau $20 \%$ apakah masih tetap toko B yang paling murah?

S: Jika diskonnya bukan $15 \%$ atau $20 \%$ pasti soalnya berubah, karena di soal barang pertama diskon $5 \%$ barang kedua 10\%, barang ketiga 15\% maka barang ke-4 pasti diskon $20 \%$ atau sekurang-kurangnya diskon 15\% (mengubah informasi), tapi karena soalnya begitu maka saya tetap yakin toko B yang paling murah. 


\section{PEMBAHASAN}

Proses berpikir siswa berkecerdasan matematis logis dalam menyelesaikan ill structured problem dapat diuraikan dengan tahapan sebagai berikut :

Tahap mengartikulasikan konteks atau ruang masalah, pada tahap ini subjek A masih tampak bingung dengan masalah yang diberikan, sehingga ia harus membaca soal beberapa kali untuk memahaminya. Ketika diberikan masalah kompleks, subjek mengalami kesulitan dalam mendefinisikan masalah, merencanakan serta mencari informasi, menafsirkan informasi yang tersedia, memutuskan informasi apa yang relevan, memilih solusi potensial, dan membenarkan solusi, hal ini sesuai dengan pernyataan Chi, T.H, Glaser, \& Robert (1985) yang menyatakan bahwa informasi yang tidak tersedia seluruhnya mengakibatkan siswa bingung untuk mengambil tindakan apa yang harus dilakukan dalam pemecahan masalah. Selain itu, ia bingung karena harga barang belum diketahui. Hal tersebut sesuai dengan pernyataan Ellspermann, Evans, \& Basadur (2007) yang menyatakan bahwa data yang diperlukan untuk menyelesaikan masalah ill structured problems biasanya tidak tersedia. ill structured problems adalah masalah yang mencirikan jenis - jenis masalah kompleks yang kita hadapi setiap hari , memiliki elemen yang tidak diketahui, memiliki berbagai solusi, beberapa kriteria evaluasi, dan membutuhkan penilaian dan justifikasi. Hal ini sesuai dengan pernyataan Chi dkk (1985); Voss, James F, Post, \& Timothy A (1988); Ge \& Land (2004) yang membahas tentang ciri - ciri ill structured problems. Subjek A bingung memahaminya karena salah satu sifat ill structured problems yaitu ambigu (sulit untuk memastikan sarana yang jelas atau tindakan yang tepat untuk membuat solusi). Sifat ambigu dalam ill structured problems karena biasanya ill structured problems memiliki satu atau lebih aspek masalah yang tidak didefinisikan secara jelas, hal ini sesuai dengan pernyataan yang dikemukakan oleh Chi dkk (1985) tentang sifat ambigu pada ill structured problems . Menurut Kuhn \& Udell (2003) serta Jeong \& Lee (2008) saat menyelesaikan ill structured problems subjek sering terlibat dalam argumentasi untuk rekonsiliasi konseptualisasi mereka yang bertentangan dari masalah, identifikasi perspektif alternatif tentang masalah, dan membangun argumen ketika mereka mengejar solusi.

Tahap identifikasi serta klarifikasi pendapat dan tahap membangun kemungkinan solusi, pada tahap ini subjek A mengurai masalah menjadi beberapa bagian penting lalu menentukan hubungannya. Pada tahap ini subjek A menafsirkan masalah, membuat hubungan antara masalah dan pengetahuan tentang domain, mendefinisikan tujuan serta ruang lingkupnya, mengidentifikasi penyebab masalah, memeriksa perspektif yang berbeda, dan menghipotesiskan solusi yang berbeda. tahapan ini sesuai dengan pernyataan Chi dkk (1985). Pengetahuan domain sangat membantu bagi peserta didik untuk menentukan informasi yang relevan dan tidak relevan, untuk mengisi informasi yang mungkin hilang dari definisi masalah. Selain itu, pada tahap ini juga siswa menentukan alternatif penyelesaian dari soal tersebut, alternatif yang dibuat oleh subjek A yaitu harga termurah di toko A atau harga termurah di toko B. Membuat alternatif jawaban sesuai dengan pernyataan Jonassen (1997) bahwa ill structured problems memiliki banyak solusi dan ketidakpastian tentang konsep, aturan, dan prinsip mana yang diperlukan untuk solusi tersebut. Tahap menilai viabilitas solusi alternatif, pada tahap ini subjek A melakukan penambahan informasi dengan memisalkan harga barang 100.000, selain itu ia juga mengubah informasi "barang ke-4 diskon 15\% atau 20\%". Penambahan informasi yang dilakukan siswa tersebut sesuai dengan pernyataan Evans (1991) bahwa perlu adanya kreativitas untuk mengatasi masalahmasalah ill structured. Tahap memantau ruang masalah, pada tahap ini subjek A melakukan penambahan informasi dengan memisalkan harga barang 100.000,00. Hal tersebut dilakukan agar lebih mudah menentukan di toko mana bisa mendapatkan barang dengan harga termurah, hal tersebut sesuai dengan pernyataan Chi dkk (1985) yang menyatakan bahwa jika hipotesis awal tidak dikonfirmasi, proses pengujian umumnya dilakukan dengan menambahkan informasi baru sehingga dapat menyebabkan hipotesis baru.

Tahap melaksanakan serta memantau solusi, pada tahap ini subjek A memilih toko B sebagai toko yang memberikan harga termurah, meskipun toko A memberikan diskon pada saat transaksi. Kesimpulan tersebut diperoleh setelah subjek A melakukan penghitungan di toko A dan B dan juga dengan menambah serta mengubah informasi pada pembelian barang yang keempat. Tahap mengadaptasi solusi, pada tahap ini subjek A tetap memilih toko B sebagai toko termurah. Hal tersebut sesuai dengan pernyataan Jonassen (1997) "Peserta didik harus memilih atau membangun solusi yang layak, merefleksikan bagaimana mereka sampai pada keputusan itu dan belajar untuk membenarkan solusi tersebut. Solusi "terbaik" adalah yang paling layak, yaitu paling dapat dipertahankan. Siswa perlu mengumpulkan bukti untuk mendukung atau menolak berbagai perspektif dan untuk mendukung setiap argumen yang dibuat. Memecahkan ill structured problems mengharuskan peserta didik mengembangkan argumen yang meyakinkan untuk mendukung solusi mereka". Pada tahap ini subjek A melakukan pengubahan informasi bahwa toko A memberikan diskon $15 \%$ atau $20 \%$ saat pembelian kedua.

\section{SIMPULAN}

Proses berpikir siswa berkecerdasan matematis logis dalam menyelesaikan "ill structured problems" menggunakan beberapa tahap penyelesaian berupa (1) memecah masalah (mengurai masalah) menjadi beberapa bagian penting (2) menghubungkan berbagai informasi yang digunakan, dan (3) menyelesaikan masalah dengan cara menambah informasi serta mengubah informasi sehingga akan memudahkannya dalam menyelesaikan ill structured problems.

Artikel ini membahas tentang proses berpikir siswa berkecerdasan matematis logis dalam menyelesaikan "ill structured problems masih terbuka kemungkinan bagi peneliti berikutnya untuk meneliti tentang proses berpikir untuk siswa berkecerdasan selain matematis logis serta bisa membahas jenis proses berpikir yang lain selain analitik. Selain itu, masih terbuka kemungkinan 
bagi peneliti berikutnya untuk meneliti dengan jumlah subjek yang lebih banyak lagi dan lebih bervariasi, misalnya menggunakan subjek yang berkecerdasan matematis logis tinggi, sedang, dan rendah sehingga tahapan-tahapan proses berpikir analitiknya lebih beragam lagi.

\section{DAFTAR RUJUKAN}

Ellspermann, S. J., Evans, G. W., \& Basadur, M. (2007). The Impact Training on the Formulation of Ill Strustured Problems. Elsevier, 35, 221-236. https://doi.org/10.1016/j.omega.2005.05.005

Evans, J. R. (1991). Creative Thinking in the Decision and Management Sciences. Cincinnati: OH : South-Western Publishing. Gardner, H. (1997). Multiple Intelligence as a Partner in School Improvement. 55, 20-21.

Ge, X., \& Land, S. (2004). A Conceptual Framework for Scaffolding Ill Structured Problem Solving Prcess Using Question Prompts and Peerinteractions. 52, 5-22.

Hung, W. (2015). Problem-Based Learning: Conception, Practice, and Future. Springer, 75-92.

Jamaris, M. (2017). Pengukuran Kecerdasan Jamak. Bogor: Ghalia Indonesia.

Jeong, A., \& Lee, J. (2008). The Effects of Active Versus Reflective Learning Style on the Processes of Critical Discourse in Computer Supported Collaborative Argumentation. Britis Jurnal of Educational Technology, 39, 651-665. https://doi.org/10.1111/j.1467-8535.2007.00762.x

Jonassen, D. H. (1997). Instructional Design Models for Well-Structured and Ill-Structured Problem-Solving Learning Outcomes. Educational Technology Research and Development, 45, 65-94.

Jurdak, M. E. (2006). Contrasting Perspectives and Performance of High School Students on Problem Solving in Real World Situated, and School Contexts. Springer, 63, 283-301.

Kitchener, \& S, K. (1983). Cognition, Metacognition, and Epistemistic Cognition: A Three-Level Model of Cognitive Processing. 26, 222-232. https://doi.org/10.1159/000272885

Kuhn, D., \& Udell, W. (2003). The Development of Argument Skill. 74, 1245-1260.

Kuswana, W. S. (2013). Taksonomi Berpikir. Bandung: Remaja Rosdakarya.

Mayer, R. (1992). Thinking, Problem Solving, Cognition. New York: W. H. Freeman and Company.

Mayer, R. E., \& Hegarty, M. (1996). The Process of Understanding Mathematical Problems. NJ: Lawrence Erlbaum Associates, 29-54.

Rahman, M. M. (2019). $21^{\text {st }}$ Century Skill "Problem Solving”: Defining the Concept. 2, 71-81.

Reed, S. K. (2015). The Structure of Ill-Structured (and Well-Structured) Problems Revisited. Springer Science+Business Media New York. https://doi.org/10.1007/s10648-015-9343-1

Rofi'i, A. (2016). Profil Proses Berpikir Siswa Sekolah Dasar Dalam Menyelesaikan Permasalahan Geometri Bangun Ruang Berdasarkan Kerangka Pikir Mason.

Saglam, Y., \& Dost, S. (2014). Preservice Science and Mathematics Teachers' Beliefs about Mathematical Problem Solving. Elsevier, 303-306. https://doi.org/10.1016/j.sbspro.2014.01.212

Siswono, T. (2008). Model Pembelajaran Matematika Berbasis Pengajuan Masalah dan Pemecahan Masalah untuk Meningkatkan Kemampuan Berpikir Kreatif. Surabaya: UNESA University Press.

Yee, F. P. (2002). Open Ended Problems for Higher Order Thinking in Mathematics. Institute of Education (Singapore), 20, 49-57.

Zhong, N., Wang, Y., \& Chiew, V. (2010). On the Cognitive Process of Human Problem Solving. Elsevier, 81-92. https://doi.org/10.1016/j.cogsys.2008.08.003 